\title{
The Theory of Social Systems Delimitation and the Reconceptualization of Public Administration
}

\author{
José Francisco Salm ${ }^{1}$ \\ Universidade do Estado de Santa Catarina \\ Gaylord George Candler \\ Indiana University South Bend \\ Curtis Ventriss \\ University of Vermont and \\ Johns Hopkins University
}

\begin{abstract}
Guerreiro Ramos's theoretical work on the Parenthetical Man (Azevêdo \& Albernaz, 2006) emphasizes the importance of a multicentric society to realize human multi-dimensionality; and specifically his Theory of Social Systems Delimitation provides a conceptual framework for understanding this multicentric society. The theory and practice of public administration has subsequently recognized the importance of multiple social sectors in the delivery of public goods. This paper will especially highlight what the subsequent theory and practice of public administration has not addressed: the importance of multiple settings in which humans can realize personal fulfillment, and enjoy (non-economic) human associated life.
\end{abstract}

Public administration has always made use of the bureaucratic organization as the principal strategy to allocate resources and to deliver public goods. Towards the latter decades of the 20th century, the dilemmas imposed by fiscal limits put pressure on the welfare state, and led to a rethinking of the public bureaucratic organization as the preferred vehicle for the provision of public services. For example, market-based reforms have increasingly been introduced, in many different countries (Almeida, 1996; Bresser Pereira, 2004). This approach has been aptly named the New Public Management. Kettl (2000) identifies the roots of the New Public Management as a search for productivity, that is, as a search for a form of government able to operate with less cost; the 
adoption of market mechanisms to overcome the deficiencies of bureaucracy; the identification of the consumer as the user of public services; decentralization in the provision of services; accountability of the producer of the services to the consumer; privatization of public services; and finally, the adoption of management by results.

However some observers worry that, as a result of the adoption of New Public Management reforms, public administration has come to be seen only through the prisms of efficiency, the reduction of public expenses, and of budgetary cuts. In such conditions, public administration becomes reduced to a mere instrumentality of the market, and no longer operates in the sphere of the public, or political domains of society. This reductionist vision of public administration has transformed the citizen to a simple client or consumer who makes decisions as if he or she was in the private sphere (Battistelli \& Ricota, 2005; Spicer, 2004; Ventriss, 2000, 2002).

One of the earliest criticisms of this nascent movement was offered by Alberto Guerreiro Ramos. Ramos echoed concerns of others that modern organization was distorting the human psyche (see Azevêdo \& Albernaz, 2006), but the target of Ramos's criticism was especially the introduction of economic influences in organization theory. Ramos offered his Theory of Social Systems Delimitation both as a conceptual tool for understanding the impact of modern organization on the human being, and as a mechanism for limiting its negative impact on public affairs.

The Theory of Social Systems Delimitation conceives society in a multicentric form, in other words, as multiple enclaves, among which the market is one. According to Ramos, society has human multidimensionality as its reference: humans are more than economic reckoning creatures. As a result, society requires multiple settings in which the human being can (importantly) realize personal fulfillment, and enjoy (non-economic) human associated life, yet while also participating in economic or market activities.

This paper will present Guerreiro Ramos's Theory of Social Systems Delimitation. On the one hand, the paper will discuss the subsequent application of the concept of a multicentric society in the delivery of public goods. More important, the paper will highlight what the subsequent theory and practice of public administration has not addressed: the importance of multiple social settings in permitting the full realization of human potential. In the next section, the paper will first present the theoretical assumptions that led Guerreiro Ramos to emphasize the 
importance of a multicentric society to realize human multidimensionality.

\section{THE RECONCEPTUALIZATION OF PUBLIC ADMINISTRATION THROUGH THE THEORY OF SOCIAL SYSTEMS DELIMITATION}

The Theory of Social Systems Delimitation represents what Alberto Guerreiro Ramos saw as the culmination of his life's work. Unfortunately, the New Science of Organizations was meant to be followed up by a second book, but he died before he could complete this work, and subsequently Ramos's work has had less impact than he had hoped. His work does represent a broad-ranging critique of organization theory on the eve of the development of the nascent New Public Management. Central to understanding Ramos's critique were both his concept of human beings, and his concept of societal affairs.

\section{The Conception of Human Beings}

The conception of humanity central to Alberto Guerreiro Ramos's Theory of Social Systems Delimitation is perhaps best introduced through the words of Eric Voegelin, from whom Ramos drew heavily. On the discovery of reason and the tension of human existence, Voegelin stated: "With regard to the organizing structure of the humanity of people, Aristotle characterized Man as a zoon noun echon, a live being who possesses Nous. The expression caught on. Through the Latin translation of zoon neotikon to rational animal, man became a rational creature and reason became the nature of man" (1978, pp. 239-240). In another passage, Voegelin referred in this way to the existential tension of which all humans are possessed:

If anything is constant in the history of mankind it is the language of tension between life and death, . . between order and disorder, truth and untruth, sense and senselessness of existence; . . between the moods of joy and despair; and between alienation in its double meaning of alienation from the world and alienation from God. If we split these pairs of symbols, . . as independent entities, we destroy the reality of existence ...; we lose consciousness and intellect; we deform our humanity and reduce ourselves to a state of quiet despair, .. of hedonistic stupor or murderous possession of truth, of suffering from the absurdity of existence or indulgence in any divertissement ... that promises to substitute as a "value" for reality lost. In the language of Heraclitus and Plato: Dream life usurps the place of wake life. (Voegelin, 1975, p. viii) 
A critical look at the values adopted in the contemporary world allows one to realize that it is exactly this that constitutes contemporary humanity, the human habitat, and the production of the public good.

The human being, as conceived by the Theory of Social Systems Delimitation, is both unique and multi-dimensional. Unique, because only the individual can act and analyze his or her own actions with freedom, finding them to be legitimate or otherwise. Therefore, only the individual can be responsible for the actions which s/he lucidly realizes, through the use of reason. The individual is multidimensional because the human being is, at the same time, a political, social and economic animal. Each of these dimensions allows the human being to develop the capacities that are necessary to realize human life (Cornford, 1976, p. 129). Individuals have a political capacity, benefit of the existence of reason; a social capacity, benefit of existence in the fellowship of other human beings; and an economic capacity, as a result of existence in the world in the private sphere. From these capacities comes the fact that the human being is free to act, through the use of reason. The individual is, especially, a being who needs to participate with others, and through participation with others to construct his or her existence and the existence of others. Because the act of participation pertains to the human condition, it is inherent in the political animal.

Reason, for Guerreiro Ramos, has been the constituent character of humanity in all eras. As conceived by the classic thinkers reason was an "active force in the human psyche that allows the individual to distinguish between good and evil, false and genuine knowledge, and, accordingly, to order his personal and social life" (Ramos, 1981a, pp. 4-5). Rationality can be classified as substantive (noetic) and functional (instrumental).

Substantially rational acts include all those intrinsically intelligent, which are based in the lucid and autonomous understanding of the relations between facts. . . . Acts or elements are functionally rational when, articulated or related with other acts or elements, they contribute to the achievement of a predetermined objective. (Ramos, 1983, p. 39)

The human being, unique and multidimensional, also is a noetic being - and could live wholly thanks to the use of the reason and consciousness of the reality of life (Voegelin, 1978, p. 14).

The duality in the attributes of reason should here be clarified. The duality of reason does not imply that there are two "reasons" in the human psyche. However the double attribute refers to two uses of reason: substantive (noetic) reason allows one to think lucidly, whereas 
instrumental or functional reason makes it possible only to calculate consequences.

To withdraw reason from the human psyche would result in the loss of the existential tension and the capacity to calculate, as well as the capacity to assess the legitimacy of the actions that one practices, and so to withdraw reason would mean that one ceases to be human. In consequence, the human being would experience self-alienation (Hegel, 1973). In this way also society, understood as Man (Voegelin, 1975, p. 98), would lose its internal tension: if one negated the predominance of reason in one's make-up, society would become a closed system (Bergson, 1977; Germino, 1982).

\section{Conception of Societal Affairs}

The Theory of Social Systems Delimitation categorizes three key settings of human existence as phenonomy, isonomy and economy. One purpose of these categories is to replace a conception of society as a uniform (especially economic reckoning) monolith. Instead, human associated life is seen as including different types of social organizations dedicated to realize different human needs. Arendt (1958) made a similar distinction to contrast the public sphere with the private sphere. In the ambit of theory that orients this discussion, therefore, the focus is on the analysis of settings of human existence within society, rather than on analysis of human society on the whole.

The first of Ramos's three settings he called phenonomy. Phenonomy refers to the personal space necessary to human existence. In The New Science of Organizations, Ramos's phenonomic spaces had a strong artistic, artisanal flavor (1981a, pp. 132-133). However, phenonomy can be seen more broadly to represent the human need for personal growth and for self-realization. In a world without personal, phenonomical spaces, substantive reason is impossible. Without this space, the human being is brutalized, experiencing self-alienation and reacting only to social laws.

Ramos's second setting is isonomy (1981a, pp. 131-132), a space of equals, of community and of participative or communal democracy. Social organizations and substantive organizations are the habitats par excellence in the space of isonomy. In The New Science, Ramos's target was instrumental rationality, which included government, market, and nonprofit organizations, to the extent that these are dominated by this economizing, instrumental rationality. However autonomous, grassroots nonprofit organizations aimed at either the public good, or at the personal development of members without detriment to the public 
good (see Candler, 1999) were clearly seen as isonomies by Ramos (1981a, pp. 131-132).

For Ramos, without isonomic settings, the human being loses the relation of equality with the other, the capacity to concretize and interact with others. The social environment in isonomy is characterized by fellowship. This equality results in participatory democracy being the best arrangement of association in society. The environment of fellowship also permits dialogue and forms of communal life.

Ramos's final social setting is "economy" (pp. 129-131). Unlike isonomies and phenonomies, economic setting is a space of unequals, in which domination is legitimized. It is characterized by efficiency in the production and allocation of goods and services. It is a space necessary to the existence of life, because without it many human needs could not be satisfied. The economic space is, therefore, essential to human existence. However when the life of the human being becomes totally regimented by the economic space, it remains vulnerable to alienation and subject to the loss of the human condition, because the person ceases to act and only comports his or her self as directed by economic imperatives (Arendt, 1958).

Despite the positive attribute of their material productivity, economic organizations could weaken society both through the shift of decision-making in society from public discourse to impersonal markets (Box, Marshall, Reed, \& Reed, 2001; Costa, 2000; deLeon \& Denhardt, 2000; Denhardt \& Denhardt, 2003; Terry, 2005; Ventriss, 2000, 2002); and in fragile societies strategic action by these organizations could weaken democracy in less subtle ways: through private capture of public policy (Bresser Pereira, 1997, pp. 28-30), even to overthrow of government. Therefore, the survival of democracy and of isonomic and phenonomic settings requires the social control of the space of action of the economy and of formal organizations, public or private. In other words, the space of the economy and of formal organizations needs to be delimited, in a democratic manner, so that the phenonomic and isonomic spaces necessary to a full human existence can be preserved.

The attempt of the Theory of Social Systems Delimitation, then, was to recognize the importance of the three types of social settings, to delimit each to what each does best and, by implication, restrict economic organizations. By delimiting economics to its appropriate space, and recognizing the importance of other spaces, human multi-dimensionality can be realized. 


\section{THE PRACTICE OF SOCIAL SYSTEM DELIMITATION}

Though an awkwardly named theory by a scholar who has been largely forgotten outside of his native Brazil (see Ventriss \& Candler, 2005), Alberto Guerreiro Ramos's theory of social systems delimitation has, to some extent, been incorporated into both the theory and the practice of public administration. Ramos was very much in touch with intellectual currents of his era. As a couple of prominent examples, consider the similarities between Robert Denhardt's In the Shadow of Organization (1981), Guerreiro Ramos The New Science of Organizations (1981a), and earlier work of John Kenneth Galbraith. Denhardt's concerns that the ethic of modern organization would lead people to "come to value discipline, regulation, and obedience in contrast to independence, expressiveness, and creativity" (1981, p. 5) echo Ramos's concerns about the impact of economic organization on human multidimensionality (1981a, pp. 109-112), as well as Galbraith's claim that people "subordinate their personality to the organization . . . men find the goals of organization superior to their own" (1967, p. 368). Denhardt's concern that to the extent most cognitive and behavioristic psychologies describe "the individual as seeking merely to rationally maximize (or even "satisfice"), they characterize the individual as achieving meaning only through the acquisition of certain 'utilities'" (pp. 45-46), echoes Ramos's concern that "the concept of rationality prevailing in current organization theory . . leads to the identification of economizing behavior with human nature at large" (Ramos, 1981a, p. 105); while Ramos and Galbraith shared concerns regarding the manipulation of human desire to acquire those utilities (Galbraith, 1952, pp. 95-102; 1973, pp. 130-160; Ramos, 1981a, pp. 80-85). Denhardt, Ramos and Galbraith also shared a concern that people in modern society had come to describe themselves through their position in the formal economy, rather than describing themselves as who they were in a broader sense (Denhardt, 1981, pp. 123-124; Galbraith, 1967, pp. 363-369; Ramos, 1981a, pp. 112-116). Galbraith probably best summed up his, Ramos's and Denhardt's concerns with his typically pithy assertion that "The nontheological quality which most distinguishes men from horses is the desire, in addition to the attributes of material and psychic wellbeing, to know, understand, and reason" (1958, p. 278).

This section will look at evidence of the concerns Ramos shared with others having been manifested in the theory and practice of public administration. More important, this section will look at the major unaddressed concern of social systems delimitation: a recognition of human multi-dimensionality and understanding of society as containing non- 
market settings in which non-economic dimensions of humanity can be realized. Especially important, and the component of Ramos's work that remains largely unappreciated by contemporary public administration scholarship, is that a multi-dimensional understanding of society should be seen not just as alternative "tools" for delivering goods and services. These settings also facilitate the realization of human multidimensionality. As Azevêdo and Albernaz put it:

The multi-dimensional model proposed by Guerreiro Ramos expands the notion of resources and of production-reduced by the market to only economic inputs and outputs - to take into consideration both remunerated activities and those non-remunerated; and activities that generate economic products as well as those that generate production of another nature. (2004, p. 23)

The central observation driving the theory of social systems delimitation was that modern society had seen organization, not least economic organizations, rise to a position of unprecedented prominence. While this had enormous positive benefits in terms of productive capacity and all that "more stuff" contributes to human happiness, it had equally serious implications in terms of its impact on other dimensions of the human psyche. Not only was modern society inadequately aware of this risk, but modern organization theory was ignoring the issue, as well. What was needed was the Parenthetical Man (Ramos, 1971), able to "transcend the organization. . ." and "defend the human being against the brutalization, the mental routinization, and alienation of modern organizations" (Ramos, 1963, p. 149). But the Parenthetical Man needed non-economic settings in which to act, and so it was necessary for society to "delimit" the influence of economics, and for organization theory to recognize the existence of these extra-economic dimensions of social activity. Hence Ramos's economy, phenonomy and isonomy.

As indicated earlier, the economic enclave does not preclude the possibility of substantive organizations and/or substantive practices within organizations in this sector (see Serva, 1997), though Ramos was certainly skeptical of the extent of this (Ramos, 1981a, pp. 82-85, 131). The literature on organizational humanism, from Maslow (1943) to the present, has been the most obvious manifestation of this incorporation of substantive concerns in organizational theory. Such a substantive organization might produce a public good, such as education for children in excluded communities; another might produce artisanal objects that result from the personal choice of those who obtain self-actualization in their production. The economic question, in these cases, is only incidental. In both cases, beyond the learning or the object that results from 
the work, there is an inseparable compensation from the act of producing this service or good. Also, in these organizational settings there is the possibility to practice human multi-dimensionality. The human being is included in her or his multi-dimensional totality in these organizations, to the contrary of the principal of partial inclusion of functional formal organizations (Katz \& Kahn, 1978).

A second example of a more humanistic, substantive approach in public administration concerns the incorporation of participation. The development of structures of consent-participatory managementwithin organizations has become fairly well-trodden academic turf (at least since Coch \& French, 1949). Still, as Collins suggests, in the private sector the results of participatory management remain mixed, and authoritative management remains common, with this in no small part due to economic justifications of what should be a substantive practice: "organization theory is still dominated by an authoritarian model with communication offered as a pragmatic (rather than ethical) challenge to the status quo" (1997, p. 491).

Incorporating public participation into public administration has also received considerable recent attention, perhaps most interestingly by King, Feltey and Susel (1998; see also Box, 1998; Denhardt \& Denhardt, 2003; Roberts, 2004; Stivers, 1994; and Vigoda, 2002). Brazil has provided especially interesting examples of this in terms of participatory budgeting (Koonings, 2004; Ribeiro, 1993; see also Ebdon \& Franklin, 2006; and Najjar, 1978, p. 510-16), but the question of participation extends well beyond this (Braatz, 1973; Gomez de Souza, 1987; Guimarães da Silva \& Rivière d'Arc, 1996).

On his conception of settings, in The New Science Ramos refers to "enclaves," and the sense the reader gets is that the author calls for almost commune-like spaces in which people can "drop out," especially avant-garde sorts like "free lance artists, writers, journalists, craftsmen, inventors and so forth" (1981a, p. 133). Instead, the theory of social systems delimitation applies more broadly in terms of alternate social spaces or settings, which one could shift between in the course of a single day: feeding the body through employment in economic organizations, but nurturing the psyche in other settings.

This especially applies to the nonprofit sector. Though Ramos argued that some nonprofits could operate with an economizing mindset (see pp. 131-132), the spirit of Ramos's isonomies is what have come to be known as nonprofit organizations. These stand out from economic organizations because of their isonomic characteristics, but also because of the significance of grants (rather than market exchange) in their 
funding (1981a, pp. 160-162), and because these "grants or one-way transfers are usually rooted in a communal-societal integrative drive" (Najjar, 1978, p. 502). Ramos also foresaw the current interest in networks, network governance (see Dixon \& Dogan, 2002; Sørensen \& Torfing, 2005), and the development of new tools of government (Hood, 1986; Salamon, 2002). His recognition of the need for extraeconomic "spaces for the creation and expansion of human potential" (Franco, 1983, p. 40) implied coordination between these spaces, and so "a variety of technical capacities of governmental intervention, of which the capacity typical of the conventional economist is only one particular aspect" (Ramos, 1979).

The importance of substantive, isonomic, nonprofit organizations is not limited to the U.S. and other developed countries. Indeed, as the nonprofit sector expanded in Brazil during the recent military government that led to Ramos's exile, non-governmental organizations came to be seen as alternatives to the state. For Castor and Franca (1986 p. 22), the exhaustion of the old state-led, authoritarian model of development of the Vargas era meant that civil society increasingly had to mobilize to manage affairs. Indeed, they argue that modern society has become too complex for the centralized state, or even a decentralized state with devolved responsibilities, to manage, so civil society should step in (see also Cardoso, 1983; Oliveira, 1981; Valadares de Carvalho, 1983; Wanderley, 1980).

The importance of isonomic organizations in developing countries can hardly be over-emphasized. For example São Joaquim, a region of six small municipios (local level of government) with a population of 50,000 in the interior of the state of Santa Catarina in southern Brazil, contains 348 formally registered social organizations, many of which have substantive characteristics. Of these organizations, $30 \%$ are financed wholly from member contributions. $22 \%$ are focused on local development, $15 \%$ on citizen education, $9 \%$ are devoted to arts and culture, $6 \%$ to social assistance, and $17 \%$ are involved in religious activities. $61 \%$ of people working in these organizations are volunteers. When questioned, $50 \%$ of participants in these organizations indicated that their involvement was motivated by a desire to reduce social inequalities, and $36 \%$ sought to reduce human suffering. The managers of these organizations affirm that $60 \%$ participate and act in groups characterized by open management (Salm \& Menegasso, 2005). According to data on social capital in the diverse regions of Santa Catarina, it is estimated that there are some 25,000 such organizations in the state. Silva argues that rural development in Brazil has lagged in large part 
due to market forces both causing a range of non-economic externalities (2003, pp. 30-41) and pushing out isonomic, communitarian spaces that might both help ameliorate these externalities, as well as contribute to the public good in other, non-economic ways (pp. 51, 196-197).

Beyond these non-economic, isonomic nonprofit settings, in the developing world the delimitation of society between market and nonmarket enclaves has more relevance. Beyond regions like São Jaoquim, subsistence production remains much more important in developing countries. Ramos long recognized the importance of subsistence production (see Ramos \& Almeida, 1957). In The New Science he refers to dual economies, and the belief among most development theorists that "development" meant reducing non-market, and growing market spaces. This, Ramos thought, was seriously wrong-headed:

Some consequences are misurbanization or overconcentration of population in great cities, increase in the rate of anomy, the aggravation of the behavioral syndrome with all its distortive psychological connotations, the dilution of the citizens' cultural identity, and the destruction of their craft competence which enabled them to autonomously guarantee their meaningful livelihood. (1981a, pp. 159-160)

A quarter century later, despite often dramatic rates of growth, the non-market sector and non-market enclaves remain important in developing countries. Subsistence as a mode of production is especially characterized by little division of labor, a heavy emphasis on agriculture, and "market exchange is not the dominant means of economic organization" (Dalton, 1971, p. 125). Subsistence has been in decline, but as Candler argues:

"Self reliance" remains strong among many rural people, as market participation is often only peripheral, with the activities of the broader capitalist national economies of negligible importance to their everyday lives. Most African economies, for instance, might better be understood as mixed (as opposed to dualistic), with significant state, market and subsistence sectors. (1997, p. 168)

Indeed, far from fading into irrelevance, non-market, isonomic, communal forms of production have especially gained in prominence given the efforts of Brazil's Movimento sem Terra in creating over a thousand settlements based on a communal model of production (Vendramini, 2005; Wolford, 2003). Along with the informal (Jones, 1995; Ramos, 1979) and household sector, which has similarly been overlooked in both the south (Ramos, 1981b) and north (Ramos, 1981a, pp. 153-154), 
Social Systems Delimitation is able to incorporate these non-economic, informal actors into an understanding of society.

\section{FINAL CONSIDERATIONS}

Critics of the New Public Management-Alberto Guerreiro Ramos being one of the earliest-have especially argued that the approach conceives of humans as narrow, economic-reckoning creatures. Many of the critiques of government that led to the New Public Management have indeed often been both narrow and simplistic, from Osborne and Gaebler's uncritical presentation of anti-government attitudes (1992, p. $\mathrm{xv}$ ) as a justification for "reinventing government," to Ronald Reagan's assertion that "In this present crisis, government is not the solution to our problem; government is the problem" (1981).

However, the excesses of advocates of the New Public Management have at least been matched by critics of the model. A critic might question, too, the tone of Alberto Guerreiro Ramos's take on cognitive politics (1981a, pp. 75-101), the degree to which instrumental (as opposed to substantive) rationality has come to dominate modern social science (pp. 3-4), the degree to which economic organizations "are free to shape the minds of their members and lives of their citizens in general" (p. 129), and his assertion that in "modern social science. . the human being is nothing but a reckoning creature and the market the paradigm to which his associated life should be organized" (p. 22). As Christina Andrews has pointed out, The New Science is also long on criticism of markets but very short on what the political alternative would look like, especially how it would avoid the failings that plagued both Communist planning (Andrews, 2000, pp. 262-265) and the mixed social democratic countries of Western Europe and Australasia (Bresser Pereira, 2004, pp. 157-172). Still, The New Science is hardly an anti-market screed. As indicated, Ramos identifies "economic" organizations as one of the three types of settings-along with phenonomic (personal) and isonomic (communal) settings-in his model, though his acceptance of market-based economic organizations at times reads grudging (p. 131)

The problem that Guerreiro Ramos identified was that organization theory and public administration "has been taught, researched, and even thought in accordance with the conceptual point of view that is a mere expression of the ideology of the market" (Cruz, 1983, p. 46). Public administration seen under the perspective of human multidimensionality requires the exercise of instrumental rationality appropriate to economic organizations. Therefore, public administration as a strategy 
of action for providing public services, should make use of bureaucratic organization, and implement market incentives where appropriate. However, the discussion presented here argues that public administration should also operate:

1. By means of the citizen, when producing the public good;

2. By means of social organizations with substantive and isonomic characteristics;

3. By means of bureaucratic organization in which participatory management is obtained through structures of consent;

4. By means of citizen participation, again through which consent is sought;

5. By means of communities engaged in the production of the public good;

6. By means of social networks; and

7. By means of social responsibility of business firms.

This implies that efficiency criteria in administrative action in the production of the public good remain important. Yet efficiency relates wholly to means: making the trains run on time. Within the U.S. context, the ends of government include a substantive Constitutional charge to "promote the general welfare." Public organizations need to ensure that their pursuit of efficiency contributes to those ends, and might also think about what government can do to promote the general welfare beyond the instrumental provision of goods and services. While Ramos hardly provided us with the final way in which to resolve the issues confronting us in public affairs, he did pose the following challenge: that it is critical to develop a multi-dimensional framework that would incorporate substantive rationality along with functional rationality in addressing our contemporary societal affairs.

\section{NOTES}

1. Translated by G. G. Candler.

\section{REFERENCES}

Almeida, H. T. de. (1996). Pragmatismo por necessidade: Os rumos da reforma econômica no Brasil [Pragmatism for necessity: The course of economic reform in Brazil]. Dados, 39, 213-234.

Andrews, C. (2000). Revisiting Guerreiro Ramos' The new science of organizations through Habermasian lenses: A critical tribute. Administrative Theory \& Praxis, 22, 246-272.

Arendt, H. (1958). The human condition. Chicago: The University of Chicago Press. 
Azevêdo, A., \& Albernaz, R. O. (2004). A paraeconomia como modelo e paradigma para a análise e a formulação de políticas públicas: $\mathrm{O}$ resgate de uma possibilidade [The paraeconomy as model and paradigm for the analysis and formulation of public policies: the rescue of a possibility]. Em Tese, 2, 20-32.

Azevêdo, A., \& Albernaz, R. O. (2006). Alberto Guerreiro Ramos's anthropological approach to the social sciences: The Parenthetical Man. Administrative Theory \& Praxis, 28 (this volume).

Battistelli, F., \& Ricota, G. (2005). The rhetoric of management control in Italian cities: Constructing new meanings of public action. Administration \& Society, 36, 661-687.

Bergson, H. (1977). The two sources of morality and religion. Notre Dame: University of Notre Dame Press.

Box, R. (1998). Citizen governance: Leading American communities into the 21st century. Thousand Oaks, CA: Sage.

Box, R., Marshall, G., Reed, B., \& Reed, C. (2001). New public management and substantive democracy. Public Administration Review, 61, 608-619.

Braatz, R. (1973). A validade de gerência participativa na cultura Latina [The validity of participatory management in the Latin culture]. Revista de Administração Pública, 7, 71-96.

Bresser Pereira, L. C. (1997). Estratégia e estrutura para um novo Estado [Strategy and structure for a new State]. Revista de Economic Política, 17, 24-38.

Bresser Pereira, L. C. (2004). Democracy and public management reform. New York: Oxford University Press.

Candler, G. (1997). Subsistence democracies: Empirical evidence from the South Pacific. Political Science, 48, 162-183.

Candler, G. (1999). Interest groups and social movements: Self or public interested? Insights from the Brazilian third sector literature. Voluntas, 10, 237 253.

Cardoso, R. C. L. (1983). Movimentos sociais urbanos: balanço critico [Urban social movements: critical balance]. In B. Sorj \& M. H. Tavares de Almeida (Eds.), Sociedade e política no Brasil pós-64 (pp. 215-239). São Paulo: Editora Brasiliense.

Castor, B. V. J., \& Franca, C. (1986). Administração pública no brasil: Exaustão e revigoramento de modelo [Public administration in Brazil: The exhaustion and reinvigoration of the model]. Revista de Administração Pública, 20, 3-26.

Coch, L., \& French, J. (1948). Overcoming resistance to change. Human Relations, 1, 512-532.

Collins, D. (1997). The ethical superiority and inevitability of participatory management as an organizational system. Organization Science, 8, 489-507. 
Cornford, F. (1976). The republic of Plato. New York: Oxford University Press.

Costa, F. L. (2000). Programa de estudos e pesquisas em reforma do estado e governance [Program of studies and research in reform of the state and governance]. Revista de Administração Pública, 34, 267-270.

Cruz, B. da, Jr. (1983). Panel comments in D. L. de Mello, Segundo painelContribuição de Guerreiro Ramos para o estudo da administração pública [Second panel-Contribution of Guerreiro Ramos for the study of public administration]. Revista de Administração Pública, 17, 35-62.

Dalton, G. (1971). Economic anthropology and development. New York: Basic Books.

deLeon, L., \& Denhardt, R. B. (2000). The political theory of reinvention. Public Administration Review, 60, 89-97.

Denhardt, J., \& Denhardt, R. (2003). The new public service: Serving rather than steering. New York: M. E. Sharpe.

Denhardt, R. (1981). In the shadow of organization. Kansas: University Press of Kansas.

Dixon, J., \& Dogan, R. (2002). Hierarchies, networks and markets: Responses to societal governance failure. Administrative Theory \& Praxis, 24, 175-196.

Ebdon, C., \& Franklin, A. (2006). Citizen participation in budgeting theory. Public Administration Review, 66, 437-47.

Franco, C. (1983). Panel comments in D. L. de Mello, Segundo painel-Contribuição de Guerreiro Ramos para o estudo da administração pública [Second panel-Contribution of Guerreiro Ramos for the study of public administration]. Revista de Administração Pública, 17, 35-62.

Galbraith, J. K. (1962). American capitalism: The concept of countervailing power. Boston: Houghlin Mifflin.

Galbraith, J. K. (1958). The affluent society. Boston: Houghton Mifflin.

Galbraith, J. K. (1967). The new industrial estate. Boston: Houghton Mifflin.

Galbraith, J. K. (1973). Economics and the public purpose. New York: Signet.

Germino, D. (1982). Political philosophy and the open society. Baton Rouge: Louisiana State University Press.

Gomez de Souza, I. R. O. (1987). A estratégia participativa de administração pública [The participatory strategy of public administration]. Revista de Administração Pública, 21, 44-53.

Guimarães da Silva, P. R., \& Rivière d'Arc, H. (1996). Participação social: instrumento de gestão pública? Elementos para um debate sobre a gestão de cidades brasileiras. Quais as perspectivas nos anos 90? [Social participation: instrument of public management? Elements for a debate on the management of Brazilian cities. What are the perspectives of the 1990s?] Revista de Administração Pública, 30, 44-70. 
Hegel, G. W. F. (1973). Philosophy of right. New York: Oxford University Press.

Hood, C. (1986). The tools of government. Chatham, NJ: Chatham House Publishers.

Jones, B. (1995). Sleepers wake! Melbourne: Oxford.

Katz, D., \& Kahn, R. (1978). The social psychology of organizations. New York: John Wiley \& Sons.

Kettl, D. F. (2000). The global public management revolution. Washington: Brookings Institutions Press.

King, C. S., Feltey, K., \& Susel, B. (1998). The question of participation: Toward authentic participation in public administration. Public Administration Review, 58, 317-326.

Koonings, K. (2004). Strengthening citizenship in Brazil's democracy: Local participatory governance in Porto Allegre. Bulletin of Latin American Research, 23, 79-99.

Maslow, A. (1943). A theory of human motivation. Psychological Review, 50, 370-396.

Najjar, G. K. (1978). Social systems delimitation and allocative mechanisms: Perspectives on budgeting for development. Administration \& Society, 9, 495-517.

Oliveira, M. L. de. (1981). Pequenas democracias. Revista da Administração Municipal, 30, 76-83.

Osborne, D., \& Gaebler, T. (1992). Reinventing government. Reading, MA: Addison-Wesley.

Ramos, A. G. (1963). Mito e verdade da revolução brasileira [Myth and reality of the Brazilian revolution]. Rio de Janeiro: Zahares Editôres.

Ramos, A. G. (1971). The parenthetical man. Journal of Human Relations, 19, 463-487.

Ramos, A. G. (1979, July 8). Um modelo corretivo do impasse econômico [A corrective model of the economic impasse]. Jornal do Brasil, pp. Especial 2-3.

Ramos, A. G. (1981a). The new science of organizations. Toronto: University of Toronto Press.

Ramos, A. G. (1981b). Notícia sobre a nova teoria econômica [News concerning a new economic theory]. Jornal do Brasil, July 26, p. Especial 4-5.

Ramos, A. G. (1983). Administração e contexto Brasileiro [Administration and Brazilian context]. Rio de Janeiro: Ed. Fundação Getúlio Vargas.

Ramos, A. G. R., \& de Almeida, C. A. M. (1957). Perspectives de l'Amérique Latine contemporaine [Perspectives on contemporary Latin America]. Encyclopédie Française, Book 11. 
Reagan, R. (1981, January 20). Inaugural address.

Ribeiro, C. A. C. (1993). Práticas orçamentárias participativas: Um estudo de case de prefeituras paulistas [Participatory budgetary practices: A case study of São Pualo town halls]. Revista de Administração Pública, 27, 28-46.

Roberts, N. (2004). Public deliberation in an age of direct citizen participation. American Review of Public Administration, 34, 315-353.

Salamon, L. (2002). The tools of government: A guide to the new governance. New York: Oxford University Press.

Salm, J. F., \& Menegasso, M. E. (2005). Capital social: Região de São Joaquim [Social capital: Region of São Joaquim]. Governo do Estado de Santa Catarina: Imprensa Oficial do Estado.

Serva, M. (1997). Abordagem substantiva e ação comunicativa: Uma complementaridade proveitosa para a teoria das organizações [Substantive approach and communicative action: An advantageous complement for the theory of organizations]. Revista de Administração Publica, 31, 108-134.

Silva, F. da C. (2003). Políticas públicas e diretrizes estratégicas para um vida rural sustentável: Um estudo á luz da teoria da delimitação dos sistemas sociais [Public policies and strategic rights for a sustainable rural life: A study in light of the theory of social systems delimitation]. MA thesis, Universidade Federal de Santa Catarina.

Sørensen, E., \& Torfing, J. (2005). Network governance and post-liberal democracy. Administrative Theory \& Praxis, 27, 139-237.

Spicer, M. (2004). Public administration, the history of ideas, and the reinventing government movement. Public Administration Review, 64, 353-362.

Stivers, C. (1994). The listening bureaucrat: Responsiveness in public administration. Public Administration Review, 54, 364-369.

Terry, L. (2005). The thinning of administrative institutions in the hollow state. Administration \& Society, 37, 426-444.

Valadares de Carvalho, N. (1983). Autogestão: O nascimento das ONGs [Selfmanagement: The birth of NGOs]. São Paulo: Editora Brasiliense.

Vendramini, C. R. (2005). A experiência coletiva como fonte de aprendizagens nas lutas das movimentas sem terras no Brasil [The collective experience as source of apprenticehsips in the struggles of the landless movement in Brazil]. Revista Lusófono de Educação, 6, 67-80.

Ventriss, C., \& Candler, G. G. (2005). Alberto Guerreiro Ramos, 20 years later: A new science still unrealized in an era of public cynicism and theoretical ambivalence. Public Administration Review, 65, 347-359.

Ventriss, C. (2000). New public management: An examination of its influence on contemporary public affairs and its impact on shaping the intellectual agenda of the field. Administrative Theory \& Praxis, 22, 500-518. 
Ventriss, C. (2002). The need and relevance for public rationality: Some critical reflections. Administrative Theory \& Praxis, 24, 287-298.

Vigoda, E. (2002). From responsiveness to collaboration: Governance, citizens, and the next generation of public administration. Public Administration Review, 62, 527- 540.

Voegelin, E. (1975). From Enlightenment to revolution. Durham, North Carolina: Duke University Press.

Voegelin, E. (1978). Order and history: Plato and Aristotle. Baton Rouge: Louisiana State University Press.

Wanderley, L. E. (1980). Movimentos sociais populares: Aspectos econômicos, sociais e políticos [Popular social movement: Economic, social and political aspects]. Encontros com a Civilização Brasileira, 25, 107-132.

Wolford, W. (2003). Producing community: The MST and the land reform settlements in Brazil. Journal of Agrarian Change, 3, 500-520.

José Francisco Salm holds a Ph.D. from the University of Southern California, where he was a student of Guerreiro Ramos. His long academic career has especially focused on service and on academic leadership. He has served as the Secretary of the Treasury for the State of Santa Catarina, and most recently as Coordinator of Graduate Education at the Graduate School of Administration and Management (Escola Superior de Administração e Gerencia-ESAG) at the State University of Santa Catarina (University Estadual de Santa Catarina_UDESC). Email: jfsalm@uol.com.br

George Candler is an Assistant Professor at the School of Public and Environmental Affairs, Indiana University South Bend.

Curtis Ventriss is a Professor in the Rubenstein School of Environment and Natural Resources, University of Vermont; and is a Visiting Professor at the Institute for Policy Studies, Johns Hopkins University (2006-7). 
Copyright of Administrative Theory \& Praxis is the property of University of Nebraska at Omaha, School of Public Administration and its content may not be copied or emailed to multiple sites or posted to a listserv without the copyright holder's express written permission. However, users may print, download, or email articles for individual use. 